\title{
COLLABORATORS AND HECKLERS: Performative Pedagogy and Interruptive Processes
}

\section{Lee Campbell}

\begin{abstract}
Arguing for the positive disruptive nature of interruption, this paper concentrates on my current performative and pedagogic usage of interruption within my teaching as the means to achieve three aims: 1) develop aspects of practice discussed in my doctoral thesis 'Tactics of Interruption: Provoking Participation in Performance Art' (Campbell 2016) related to the focused usage of interruptive processes in contemporary art practice (Arlander 2009: 2) provide students with direct experience of how interruption may command immediate reaction and force collaborative means of working, i.e. collective survival tactics to deal with interruption; and 3) theorise, articulate and demonstrate how interruption relates to critical reflection (on the part of both student and teacher), extending the ideas of Maggi Savin-Baden (2007) to propose interruption as reflection. To achieve these aims, the paper discusses how I have implemented interruption into learning activity design and evidences how I have created activities that aim to help students understand collaborative learning in cross-disciplinary projects through an effective use of realia (interruption is part of real life). I discuss one first year teaching seminar at Loughborough University in March 2015 (and subsequent related iterations) combining performance, fine art and collaboration methodologies where students directly engaged in a range of activities not displaced from their own life experiences; there was heavy student engagement in digital technologies, and interruption. The main outcomes of the teaching session support and go beyond the aims by relating to: a) experiential learning related to the interplay between 'collaboration' and 'interruption'; b) performative pedagogy and inclusion; c) the interplay between teaching, liveness and interruption; and d) performative pedagogy and the exchange of power relation.
\end{abstract}

\section{Introduction: provoking participation}

As part of a guest lecture that I gave at University College Cork, Ireland in May 2016 entitled 'Provoking Participation: Tactics of Performative Pedagogy', 
the chair Professor Manfred Schewe posed a question that is at the core of my practice as both a teacher and performance artist: "What happens when performative arts meet pedagogy?" and went on to suggest the following:

In any pedagogical situation, you want the learners to feel safe. On the other hand, you must know that you may be faced with group where there isn't a lot of dynamics, there's a lot of sleepiness and so on, and you [the teacher] want to somehow make them active, challenge them. Performative arts would have a lot of strategies.

To initiate discussion of Schewe's suggestion, this paper relates to my usage of performative art (specifically related to the act of interruption as a performative technique to provoke participation) and disseminates important aspects of my pedagogic strategy relating to how I apply my knowledge and expertise as an artist to generate performance practice with an emphasis on participation in my classroom.

As a teacher and a performance artist there are clear links between how I spark the engagement and participation of an audience during one of my performance works and how I attempt to do the same with students in the context of my classroom. My teaching philosophy emphasises experiential learning in the form of 1) the usage of collaborative learning processes and co-learning and 2) reproducing real life in the classroom by incorporating realia (objects from real life used to improve students' understanding of real life situations).

My previous experience as an EFL teacher of deploying performative pedagogy to help learners get to grips with the target language was significant in developing and forefronting my current interest in performative learning and teaching, Where I promoted a collaborative approach to learning to build social confidence amongst groups of students who often spoke different languages and were from entirely different ethnic origins, I used performative play as a key strategy. Role-play situations that utilised everyday realia, through their use of day-to-day conversational gambits all helped to generate positivity through forms of convivial humour and laughter intended to alleviate anxiety and pull down social barriers. ${ }^{1}$ A fun way of teaching the names of different parts of the body to beginner level students was by using performative pedagogy. Firstly, students worked in groups and stuck post-it notes with the names of body parts to another student's body (Figure 1).

To concept check that students had remembered the vocabulary, games that were bodily in nature were used to punctuate understanding; the simple but effective Head, Shoulders, Knees and Toes song with its corresponding body gestures to be enacted whilst being sung always got a cheer with younger students. Another popular activity encouraged students to invent an imaginary person looking for love, fill in a brief form with dating requirements of their

\footnotetext{
${ }^{1}$ It could be argued that the reason teachers want students to be relaxed during class is because then they will have lowered their affective barrier making them more likely to remember what is taught to them. Furthermore, Russian theatre practitioner Konstantin Stanislavski devised relaxation designed to free creativity (Benedetti 1989).
} 


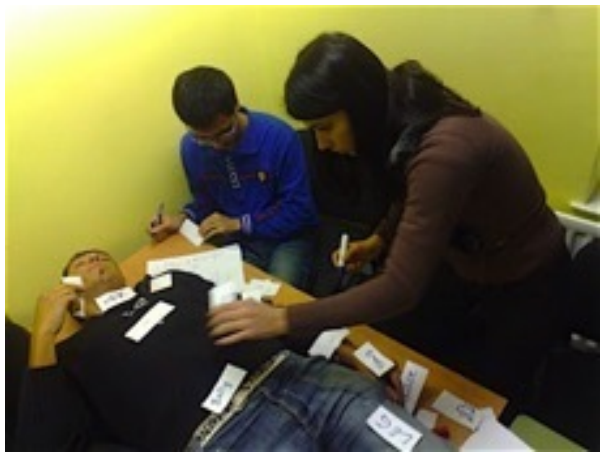

Figure 1: Post-It Note Body Parts Lesson. (2009) United International College (UIC) London

imaginary person and then undertake a live speed-dating style activity in the classroom enacting their imaginary person seeking out a date. Students often enjoyed taking on the role of a persona/acting (Figure 2).

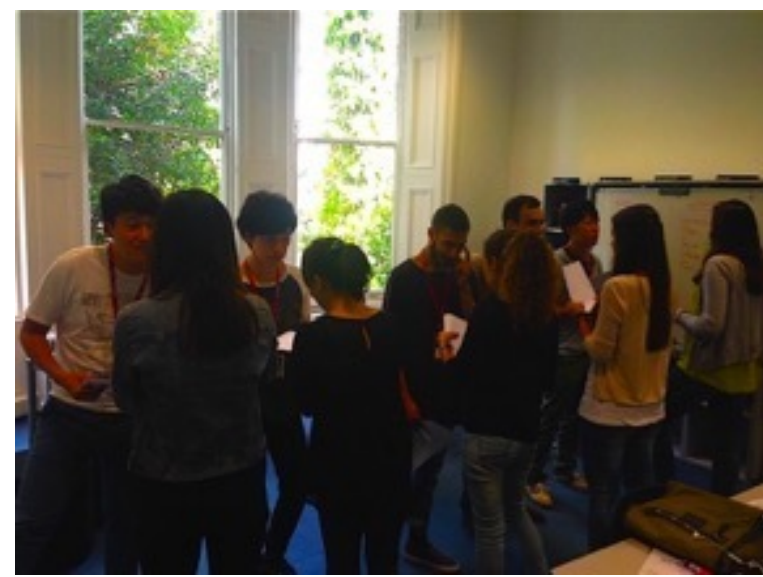

Figure 2: Speed-Dating Classroom (2014) Frances King School of English, London

Between 2009-2010, instances of my Performance Art practice deployed EFL as providing inspiration for subject matter/content and narrative. I curated a series of performances entitled Tefltastic! drawing together teachers and students to perform in public together in a variety of locations around London (shop fronts, art festivals, library lecture halls etc.). One iteration of Tefltastic! took place at Bethnal Green Library Lecture Hall where artists (including myself) reflected upon their previous experiences of teaching EFL by generating artworks that provoked the participation of the audience. Prior the event, I asked each artist to write a hypothetical lesson plan to be delivered as a performative artwork. $^{2}$ Whilst my response and that of artists Phil Harris, Adrian Lee and Patrick Loan was to lift various activities that we use in the EFL classroom and re-configure them for this event, Heidi Wigmore's artistic contribution (Figure 3) consisted of a drawn narrative documenting her experience of teaching EFL

\footnotetext{
${ }^{2}$ Appendix 1 contains a copy of Patrick Loan's lesson plan.
} 
in Taiwan in $1986 .{ }^{3}$ Wigmore (pers. comm. 2010) suggests her aim was to:

[...] communicate a complicated narrative pictorially through bold line drawings in a 'whiteboard' style and simple words [...] The audience's challenge was both physical - to 'keep up' with the manic activities of the artist - and cognitive - to take their own journey of semiotics through piecing together the narrative.

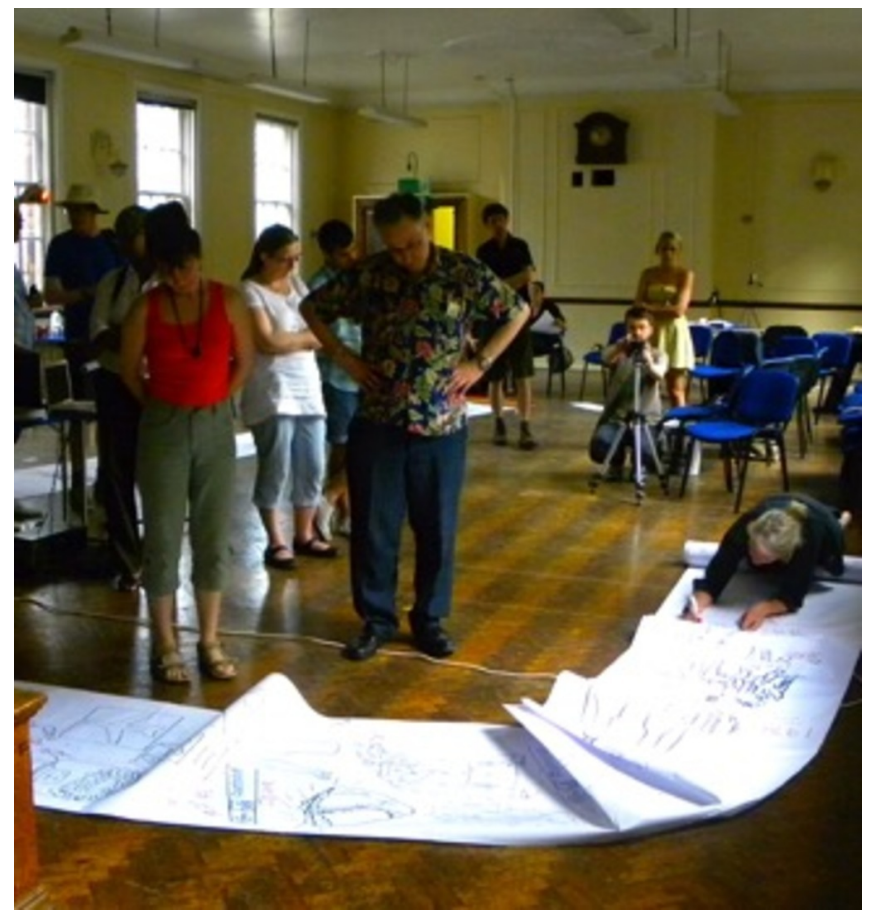

Figure 3: Heidi Wigmore's drawing performance at Tefltastic! Bethnal Green Library Lecture Hall, London (2010)

Recently, I have built upon these examples of my EFL experience above and generated a form of performative pedagogy that extends my practice as an artist/performance maker who deploys interruptive processes to galvanise participation in Performance Art. In the following section, I outline my usage of interruption within Performance Art to foreground forthcoming discussion in this paper of my use of interruption as a more extreme form of provoking participation during my teaching.

\section{Provoking participation: interruption as a performative tactic within Performance Art}

Within the discourse of impoliteness study (Bousfield 2008; Culpeper 2011 et al.), there is a term that deserves attention: 'interruption.' I define the

\footnotetext{
${ }^{3}$ For a filmed excerpt of Heidi's performance and video documentation of other artists' performances, see: https://www.youtube.com/watch?v=_9v3WzELaTA.
} 
term 'interruption' as disruption in terms of action related to the production of stops, ${ }^{4}$ pauses and breaks within the otherwise smooth running operations of an event or action in motion at the time of the interruption. I define these stops, pauses and breaks as surprise moments that derail expectation in terms of what is pre-supposed to occur in the logical narrative of something.

Artists associated with the historical art movements Dadaism and Futurism often sought to provoke by employing interruption. For example, the Futurists used extreme methods of disruption to shock their audiences. By gluing audience members to their seats and purposefully selling the same ticket to more than one person, Futurists enhanced the theatrical experience of their performances by creating planned yet still genuine and spontaneous interruptions from their audiences. As an artist/provocateur, I define my practice as playing with the parameters of contemporary art practice by focusing on the performative and can be characterised as participative art performance that, in the spirit of Dadaism and Futurism, heavily deploys interruptive processes to provoke.

Fall and Rise (25/06/08), a participative art performance that took place on a beach on the Thames Estuary as part of Whitstable Biennale, was entirely dependent upon my ability as its protagonist to engineer a carefully timed moment of physical and bodily interruption within performance (Figure 4).

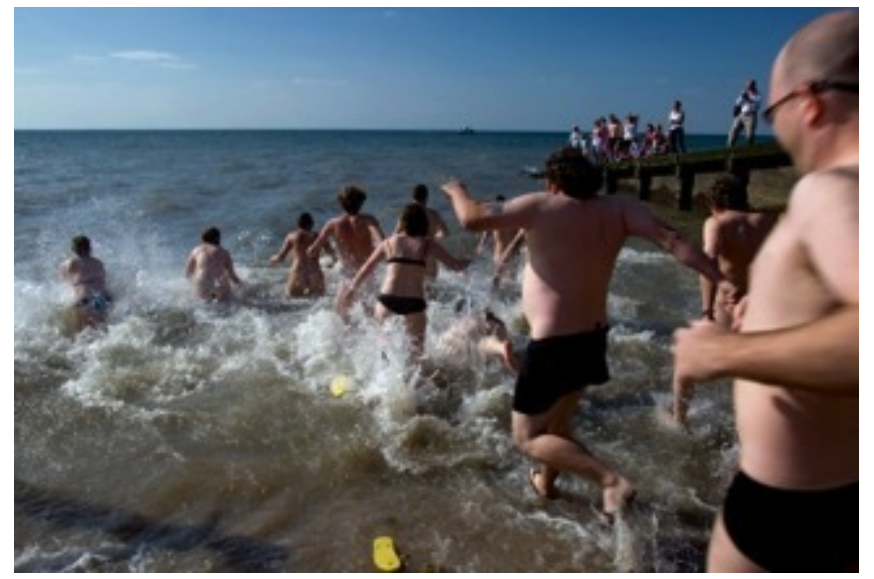

Figure 4: Lee Campbell: Fall and Rise, Whitstable Biennale (2008). Courtesy of Simon Steven

What I learnt from performing Fall and Rise was how to generate an activity that may be seen in British culture as impolite behaviour (stripping off in public for some is considered rude and socially unacceptable) by using interruptive processes that were directly physical and bodily. Akin to flashmobbing as a form of performative interruption disrupting the process of people's habitual

\footnotetext{
4 This description of interruption as a 'stop' picks up on French filmmaker François Truffaut's fascination within interruptive 'stops' in filmmaking in relation to processes of narrative. Tom Gunning (1995: 120) suggests "When Truffaut (Francois) said that he loved the moments in film when the narrative stops, he seemed to announce a whole generation's preoccupation with the contingent and non- narrative elements of film practice [...] narrative seems to still carry an ambivalent react, a taint of ideological conformity and containment."
} 
day to-day goings on, e.g., the Guerilla Girls' flashmob-style interruptions from the 1970s, the performance began with demonstrations of physical and bodily interruption. These took the form of participants (myself included) marching down Whitstable High Street blowing whistles, banging drums and chanting using a megaphone (me) to provoke the attention of passersby. We made our way onto Whitstable beach and undertook a collective act of streaking that would re-appropriate the moment where Reggie Perrin strips and runs into the sea in the BBC TV programme The Fall and Rise of Reginald Perrin.

Examining interruption and exploiting its virtues using practice brings out some productive insights that go beyond abstract theorisation. On the one hand, commentaries relating to the operations of interruption have branded interruption negatively, as a violation (Bilmes 1997). My work draws on Juliana Brixey, Kathy Johnson-Throop, Muhammad Walji and Jiajie Zhang's (2004) past work, which supports my argument that 'interruption' can have a positive dimension. They propose a theoretical framework to help explain the "positive aspects of interruptions" in which "warnings \& alerts, reminders, suggestions and notifications are examples of interruptions that have beneficial outcomes by changing and influencing behaviour" (2004: 1416). They claim, "there is little understanding how interruptions can be exploited for positive outcomes" (ibid. 1417). In a January 2015 episode of the BBC World Service's radio programme The Forum entitled Interruptions, the host Bridget Kendall stated: "Interruption can be a cause of disruption, but sometimes [interruption] can strengthen and support us" (Kendall 2015, BBC Interview). American linguist Debra Tannen stated: "What's so fascinating about interruption is that it's a negative thing" (ibid.). I argue that disruption caused by interruption is not wholly negative; disruption can lead to positive outcomes. To sum up, commentaries relating to the operations of interruption have branded it negatively; a "violation" (Bilmes 1997), my work finds allies in commentators positively promoting interruption as "supportive" (Hutchby as quoted in Bousfield 2008; Kendall 2015), "creative" (Arlander 2009) and "poetic, lyrical and unexpected" (Cotter and Tawadros 2009). Ian Hutchby (1992) identifies interruption as transformative and argues that it has a positive dimension; "we have to do this [interrupt] to save the world" (Hutchby 1992 as quoted in Bousfield 2008: 233). My work aligns itself with this promotion of interruption.

Circumventing commentary of interruption that often posits the term and its affiliation with impoliteness and capacity to be disruptive as negative (Bilmes 1997), practice-as-research contained with my doctoral thesis (Campbell 2016) employed interruption as its key strategy to investigate the relationship between Performance Art, participation and power relations. As an outcome of my performance Fall and Rise (2008), works of Performance Art discussed within my thesis further expand the possibilities of generating interruptive processes through examples of my work as 'interruptions': practical demonstrations of the operations of interruption in different locations with amplified consideration of its physical, bodily and linguistic nature as impacting upon engaging participatory processes. 
Despite interruption - and the related notions of dissonance, dissensus, antagonism and disruption - being already wholeheartedly debated in the arts and humanities, little discussion exists focusing upon the potential for interruptive processes within the context of Performance Art and none that specifically addresses the physical dimensions of interruption as a performative technique that directly relates to the physicality of the body and of language. My thesis argues that disruption falls under the umbrella of interruption as a series of possible tactics and forefronts examples of Performance Art undertaken as practice as research to theorise, articulate and demonstrate that interruption can be used as a tactic to provoke participation. I selected slapstick and heckling as offering similar and contrasting understandings of the operations of interruption in practice. Whilst slapstick and heckling both provide useful understandings of the physical nature of interruption, I made divisions between the two forms: slapstick as related to interruption which is physical and bodily (bodies being clumsy by falling over etc.) and heckling as being physical and linguistic (you can interrupt using your body by putting your hand up, standing up, running onto a stage, walking out and so on as well as shouting something out in order to gain a reaction from those you are listening to/watching).

The performance Lost for Words (2011) and the collaborative project Contract with a Heckler (2013) are presented as prime examples of the operations of interruption in practice. Both works attend to the physical nature of interruption yet offer contrasting perspectives.

Lost for Words demonstrates interruption that is physical and bodily, whilst Contract with a Heckler demonstrates interruption that is physical and linguistic. Lost for Words supports the difficulties of participation when interruptive processes connected to physical and bodily slapstick are structurally engineered into a live performance and Contract with a Heckler supports power relations when live performance is predicated upon physical and linguistic interruptive processes relating to heckling. As I shall later discuss, I have since extended aspects of Contract with a Heckler (related to the activity of planting hecklers in an audience as an explicit form of interruption to provoke participation) into teaching activities that I have set up.

\section{Provoking participation: interruption as a performative tactic within the classroom}

I argue that interruption can be used a tactic to provoke participation. Whereas my previous usage of interruption related to the context of art/performance, I was keen to find out how interruption could be effectively used within a pedagogic context, i.e. in the classroom.

Collaboration is a core issue that relates to Fine Art practice (Billing, Lind \& Nilsson 2007). The paper now concentrates on an instance of my teaching at Loughborough University (referred to as LU thereafter), in which I delivered a seminar-style session to a group of Year One undergraduate students of Fine 
Art. The seminar set out to provide a stimulating, challenging and innovative teaching and learning environment for students and teacher to explore the nature of collaborative art practice. The seminar entitled Performance and Collaboration was held on March 23 ${ }^{\text {rd }}, 2015$ and was composed of single honours Part A Fine Art students. The seminar built upon students' contextual understanding of the topic by picking up on points that I had previously addressed in a lecture to the same students a day before which introduced them to the topic of Collaboration (within Contemporary Art Practice) with a particular emphasis on collaborative ways of working.

Using Dick Higgins' term "between media" (2001: 49), the methodological approach that I adopted when devising the seminar heavily related to aspects of intermedia practice; combining disciplines often related to Performance and Fine Art into one activity to create something new by thinking across boundaries and crossing them. As shall now be discussed and reflected upon, the session knit theory and practice together and enabled students to first, get to grips with key concepts and theoretical ideas relating to collaboration; secondly, arm themselves with the language they needed to describe aspects of art collaboration, and thirdly, generate creative performative works that lie formally and conceptually between established media. The emphasis of this practical seminar was on 'learning in action' and accentuated to students the importance of process, of 'trying things out,' whilst building their own confidence and knowledge of artistic collaboration.

Self-reflection underpins my working methodology, looking back to look forward. In my doctoral thesis, I developed a three-stage learning process: Anticipation, Action and Analysis. The writing style that I use in my description preceding, during and post this instance of my teaching practice relates to this three-stage teaching process that extends an existing model of reflective practice (Rolfe 2001) and has been described as an "original, practical and imaginative way of demonstrating reflective practice" (Newbold, pers. comm. January 2016). This process - Anticipation, Action, and Analysis - provides the basis for discussion of the teaching session in question.

In the first stage, Anticipation, I devised a set of aims and objectives based on the module specifications and intended learning outcomes related to the students in my cohort. Based on my existing knowledge, teaching experience and intuition, I devised a set of projections as to what may happen during the session (the enactment of practice upon theory). In the second stage, Action, I executed the delivery of my planned teaching activities to fulfil my aims and objectives. Assessment of how students had got to grips with the intended learning outcomes was tested via statement and response, discussion of 'collaboration' in both theory and practice and then subsequent concept checking. In the third stage, Analysis, I assessed the outcomes of the teaching session in relation to my aims and used a style of writing that, in places, takes the form of a conversation with myself to accentuate personal and emotional response and clarify the role and importance of practice. To help with my assessment, I referred to reflective writing that I produced at the time. I 
make direct reference to comments made by my colleague who conducted peer observation of this session. I then refer to subsequent teaching sessions that I gave at Central Saint Martins (referred to as CSM thereafter), University of the Arts London and University of Lincoln (referred to as UoL thereafter), where I repeated the heckling/collaboration activity that I trialed at LU. I make use of reflective writing produced by students attending those sessions. To help evaluate my focused usage of interruption within pedagogic processes, I then consider the related work of others with specific emphasis on the exchange of power relation. To conclude, I sum up the key outcomes of my usage of interruption during the LU teaching session and in other higher education institutions.

\subsection{Stage One: Anticipation}

When I was asked to design, plan and deliver this session, my immediate reaction was to generate a learning environment for students that would be as discursive and interactive as possible. Furthermore, I intended to take advantage of the students' familiarity with the topic being discussed, as they had already some experience of working collaboratively in their studio practice through a drawing-based project that invited collaborative ways of working amongst Part A students. I wanted to use this seminar as an opportunity to facilitate a social platform for the students to reflect upon that experience and to think about how they might act upon it. Knitting together both theory and practice, it was my intention for the seminar to not only focus on theories of collaboration but also address collaboration in practice by bringing practice into the room in which students experience collaboration in practice first-hand. It was my intention to discuss what may constitute the protocols of collaboration, how to encourage potential collectives and embrace differences and similarities, and for students to think about a set of questions including: 'What are the problems of collaborative practice?' and 'How can problems (associated with collaboration) be creative?' What I wanted them to leave with, having undertaken the tasks that I had planned, was not only a heightened awareness of some of the advantages and problems connected with collaboration but also an ability to theorise, articulate and demonstrate an understanding of collaboration and aspects of interruption and their associated theories in practice.

Prior the session, I informed students the structure of the session would directly relate to how I applied my Anticipation, Action and Analysis process to my focused exploration of interruption during my doctoral studies:

1. 'Anticipation': making a set of predictions informed by theory and argument relating to interruption and using one's intuition and experience; 2.'Action': executing practice based on those predictions, in order to gain experience of the operations of interruption in practice and to lend a different understanding to its associated theories; 3. 'Analysis': reflecting upon what happened in the last stage, considering how the practice 
extends the theory and context of interruption in practice through embodied and emotional response. (Campbell 2016: 49)

To explain further, during the 'Action' section, teaching activities would invite students to creatively respond to varying levels of interruption in the position of an audience interrupting and/or in the position of performer experiencing being interrupted. I was intrigued to find out what combat strategies or 'survival tactics' the students would use to deal with being faced with interruption (Hound 2011) in relation to how I dealt with heckling and interruption during Contract with a Heckler, as aforementioned and to be discussed later in this paper. Students could then apply this experience directly in terms of analysing selected examples of contemporary performance practice that contain direct physical and linguistic interruption. ${ }^{5}$

I also informed students that as part of ongoing Continuing Professional Development (referred to as CPD thereafter) that I was engaged in at the time, ${ }^{6}$ the session would be observed by one of my colleagues.

\subsection{Stage Two: Action}

Time-chronological sequence of key critical incidents/events:

14:00

Students arrive and take their seats. The peer observer takes her seat and the session gets underway. I welcome the students and inform them that the lecture is going to address aspects of contemporary Fine Art with a particular emphasis on collaborative practice with performance related outcomes. I alert students to the etymological roots of the term 'collaboration', which come from 'collaborare' meaning to work together, and can also mean working with a traitor. I suggest this latter definition may come up in discussion today. I then set out the learning objectives, key aims of the session and how the intended learner outcomes relate to the module learner outcomes. ${ }^{7}$ The session makes use of blended learning and the flipped classroom approach. Prior the session, students were invited to comment upon what they think could be the possibilities of collaborative art by using Textwall to post their responses and ideas. To elicit key concepts

\footnotetext{
5 These examples included Forced Entertainment's Bloody Mess (2002-2011) and And On The Thousandth Night (aka The Kings) (2003), in which the storytelling structure has a rule where performer and audience members are allowed to interrupt and change the story throughout its long duration (up to 12 hours) and DV8's Can We Talk About This (2012), a performance that makes direct usage of heckling in performance by including a moment in its structural engineering where an audience member shouts, "This is Islamophobic shit" two-thirds of the way through.

${ }^{6}$ Continuing Professional Development (CPD) is "the term used to describe the learning activities professionals engage in to develop and enhance their abilities" (CPD 2016).

7 The learning objectives related to: 1) understanding key concepts relating to collaborative art practice; 2) use performance-related methods to understand collaboration in practice; and 3) develop effective communication skills through the use of e-technology. The learning objectives supported the module learning outcomes by building upon existing collaborative work in the form of the drawing project that students had undertaken prior the session.
} 
and ideas even further in the physical classroom, students then brainstorm and mind map ideas using a post-it note discussion and then convert these into Wordle.net images to help build their critical vocabulary. This activity helps me to assess how students prioritise certain emergent subsidiary concepts relating to 'collaboration' and aid in forthcoming concept checking.

Students are asked to come up with 5 nouns/adjectives that for them define 'collaboration' and to write these terms on post-it notes. The post-it note 'visualisation' helps students put their ideas into concrete terms and visualise how they would look on Wordle.net. Their learning process starts with 'analogue' media like post-its/pen and paper before it is translated digitally (Figure 5). I pick up a selection of their written on post-it notes and attempt to display a selection of these via projection to the class by using the teaching room's visualiser. I have trouble in switching on the visualiser. A student assists and corrects me.

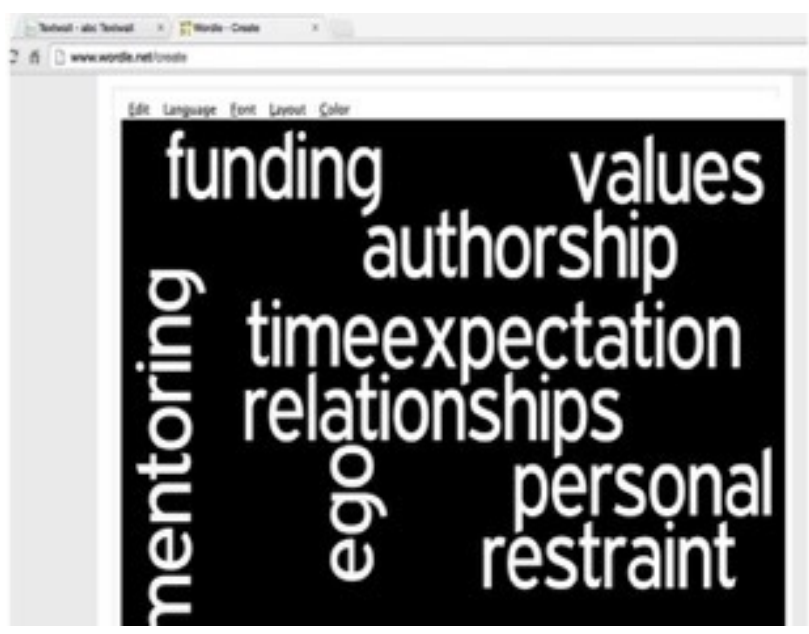

Figure 5: One of the Wordle images produced by students during the session

$$
14: 25
$$

To foster collegiality with the students I give examples of my own professional work relating to the topic of collaboration. ${ }^{8}$ These examples contain varying levels of positivity and discomfort (in terms of interpersonal relations between collaborators in terms of collaboration) and I wanted to remind and re-enforce to students some of the term's problematics. I had also intended to punctuate student understanding of the topic through a combination of physical speakers and virtual/online speakers via Skype who have engaged in collaborative art practice. I had planned to invite speakers to give short five-minute presentations as this would enable students to be exposed to a range of useful interpretations on the topic, as well as encounter professional artists working in the field of collaborative art practice. Unfortunately, this is not possible due to technological constraints in the room that the teaching session was being held in. $14: 45$

\footnotetext{
${ }^{8}$ See Appendix 2 for further information on the examples addressed to supply more context.
} 
Directly applying my previous experience of staging interruption during my doctoral research e.g. Contract with a Heckler, the key performative component of the session consisted of engaging the students in staged interruption. I divide the students into two groups. The first group are instructed to create a short performance lasting no more than 3 minutes and make use of whatever they had bought with them to the classroom as props. The group then leaves the room to rehearse (Figure 6).

GROUP A
Make a short performance last 3 minutes.
Decide who is going to perform. Maybe nominate a director. I am not
lookng for Shakespeare! Use what you have bought with you today as
props. The subject of the performance can be anything, it could be a
speech, a provocation, it could be a comedy sketch. The choice is yours!
Please leave the room and rehearse outside. I will give you ten minutes
rehearsal time. GO!.. YOUR AUDIENCE AWAITS...

Figure 6: A PowerPoint slide used during the session

I instructed the group remaining in the classroom to be impolite and interrupt the performance that they were about to witness (Figure 7).

GROUP B
You are not a polite audience.
At some point throughout the performances I want you to
interrupt the performers.
Use whatever you have bought with you today to heckle.
You can use speech, paper aeroplanes etc.
(but no throwing sharp metal objects!)
Work together and decide on your tactics of interruption.
You have ten minutes to become professional hecklers!

Figure 7: A PowerPoint slide used during the session

$15: 20$

Students are encouraged to reflect upon what happened during the practical side of the seminar by discussing interrupting and being interrupted because of their experience of one of these actions. Students are asked to fill in a question sheet which asks them the following question: 'How did the activity we have just undertaken make you think more about the creative potential of using interruption in a sophisticated way?'

\footnotetext{
${ }^{9}$ A selection of the students' responses included in Appendix 4 are discussed in the Analysis
} 
Questions to Group A included asking the group to describe how they felt their performances went, how they felt when they were interrupted and did they feel their fellow performers made a good comeback. Questions to Group B included asking the group to describe how they felt interrupting Group A's performances, which group members generated the most disruption through their interruption and did they feel the performers made a good comeback. The emphasis on asking students to give their embodied and emotional response to practice proceedings underlined the importance of bringing practice into the classroom to supply students with an understanding of interruption as well as collaboration that they could not anticipate by using theory alone.

The performance by Group A involved students telling jokes to the audience. An audience member started booing but the performers took no notice. Some audience members started throwing paper airplanes. Another audience member stripped off to his underpants. Another audience member picked up her bag, put on her coat and left the room. The performers, although looking slightly bemused, carried on with their performance. I looked over towards the observer. She did not flinch or seem perplexed at what was happening. ${ }^{10}$

15:40

Students use their experience of generating performative interruption to build a further critical vocabulary around the term 'collaboration.' I refer back to my participation in BIAW (2010), the three-week residency that I took part in which prioritised the importance of collaborative ways of making art practice (as previously mentioned in Appendix 2) and highlight the nature of focused discussions taking place during a public symposium that was held at the end of the residency (Figures 8-9).

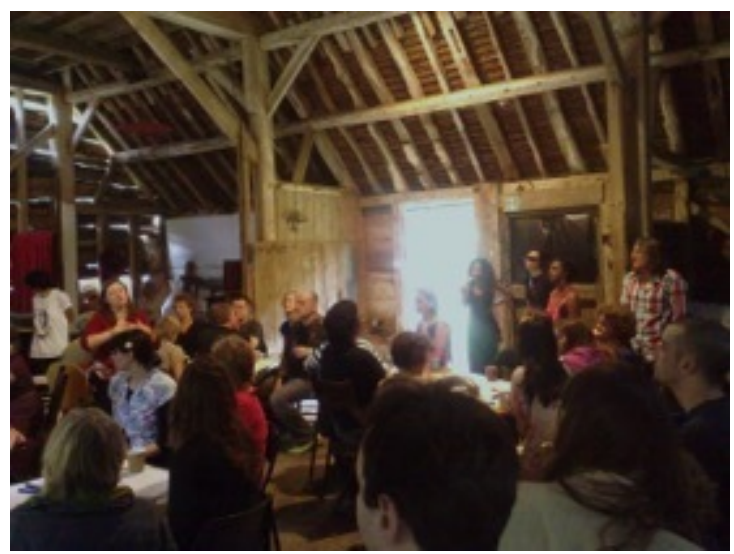

Figure 8: Public symposium at BIAW (2010)

To extend discipline-specific and generic literature and fuel students' awareness of a contextual framework, I draw upon my own expertise of artistic collaboration and use realia to initiate a whole class discussion. I distribute

section.

${ }^{10}$ I emphasise discussion of this event during the session in relation to what the students learnt and some of the questions raised in the following Analysis section. 


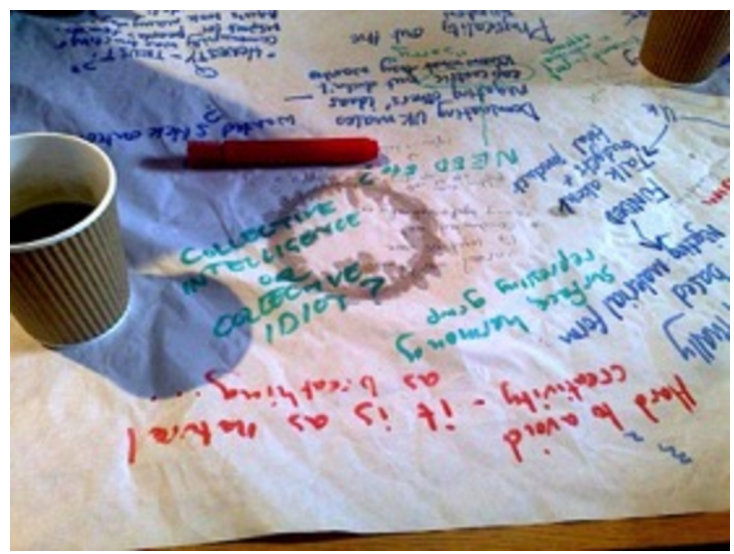

Figure 9: Public symposium at BIAW (2010)

a set of handouts to groups of students, which contain notes made during roundtable-style discussions at the symposium focusing on the resident artists' intentions and experience of collaborative working during the residency. ${ }^{11}$ Students are asked to identify key ideas as contained in the handouts and reflect upon how they have discussed similar ideas during this teaching session in both theory and practice. As an entire class activity, the students work together to identify their own Top Ten key concepts that relate to the term 'collaboration' and to produce a Wordle.net image using their ten chosen concepts (Figure 10).

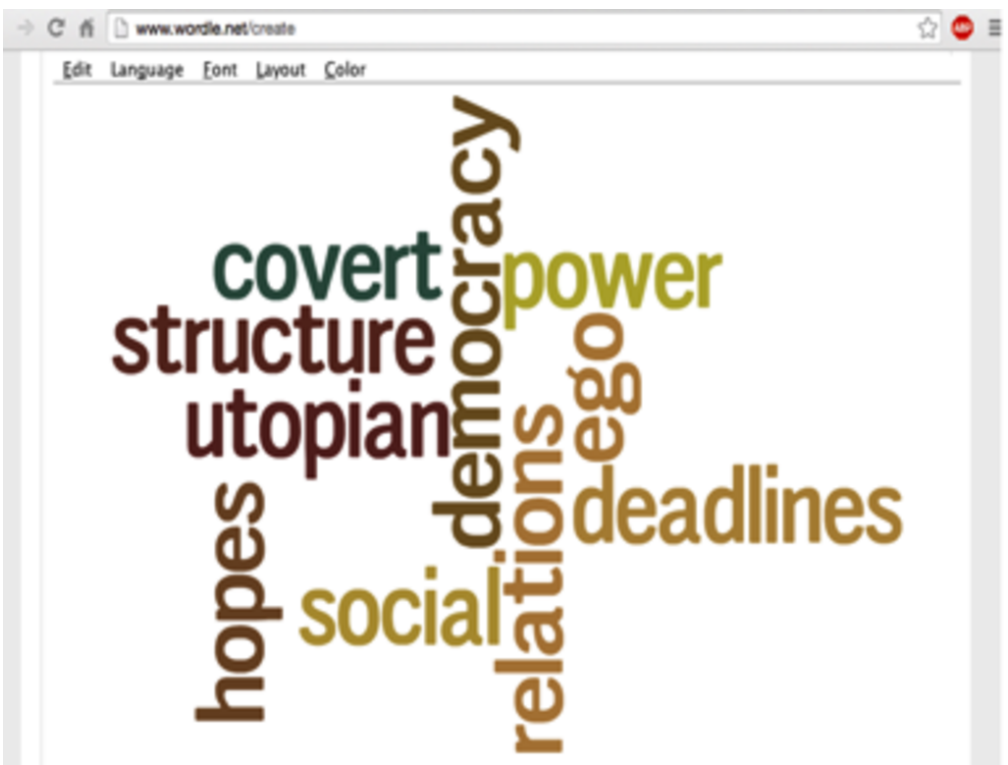

Figure 10: Wordle.net image of the class' Top Ten keywords related to the term 'collaboration'

Students have a chance to compare how they now conceptualise the term

${ }^{11}$ Appendix 3 contains a selection of these handouts. 
collaboration and discuss what they have learnt about collaboration today by using realia taken from an historical instance (my participation during the residency) where the often-tricky nature of collaboration was made real-life. Students then stick post-it notes with how they articulate the term 'interruption' to a projection on the classroom wall. Students reflect upon their experience of interruption by bringing forth different concepts that have emerged as a result of undertaking the 'interruptive' performances (Figures 11-12).
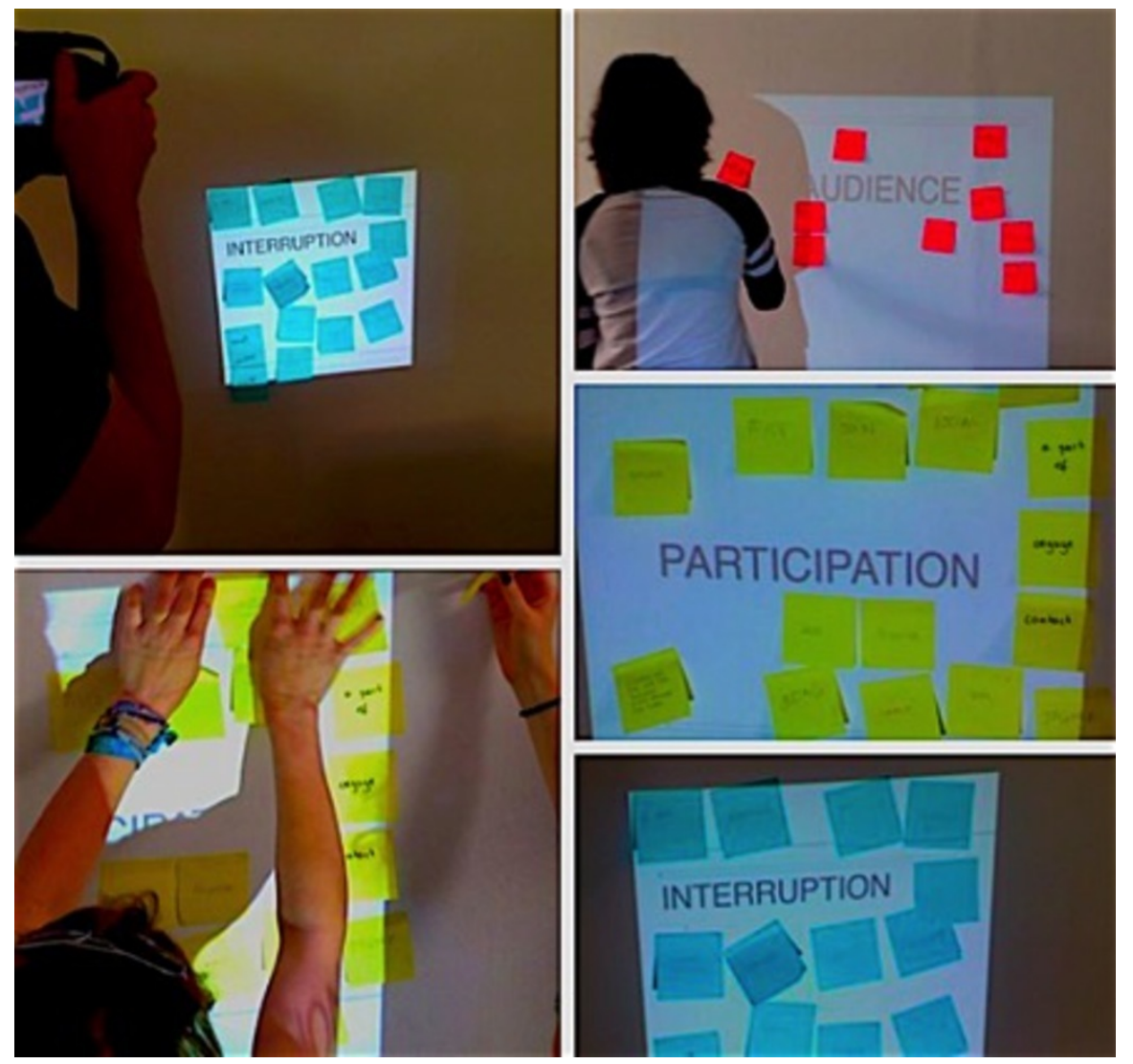

Figure 11: Students make further post-it note contributions to projection wall

At the end of the session, I refer back to Textwall and initiate discussion with students about postings that have taken place throughout the session (Figures 13-14). The session wraps up with a review of the learning objectives and how the session has gone some way in achieving these. Students comment upon what they saw as the benefits of the varying interruptions; for many of the Group A students, the interruptions by Group B helped them to think on their feet, be spontaneous and improvise.

\subsection{Stage Three: Analysis}

This teaching session was planned to enable students to explicitly make connections, by requiring them to draw on previous learning related to 


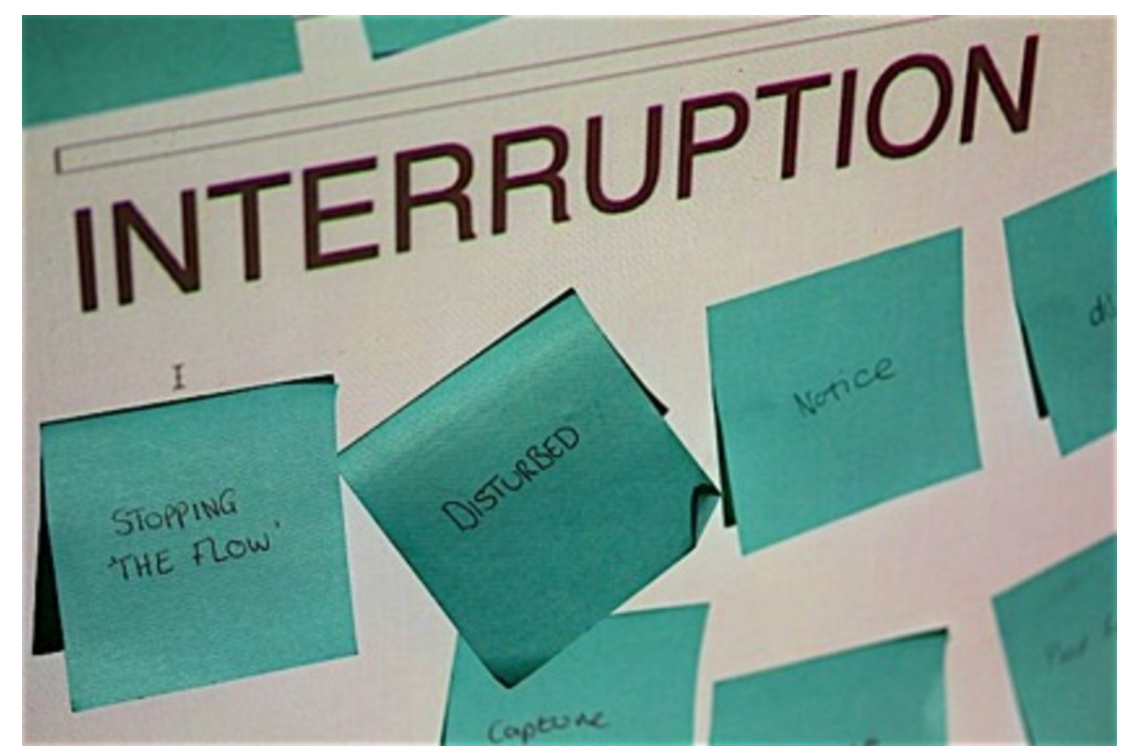

Figure 12: Students make further post-it note contributions to projection wall

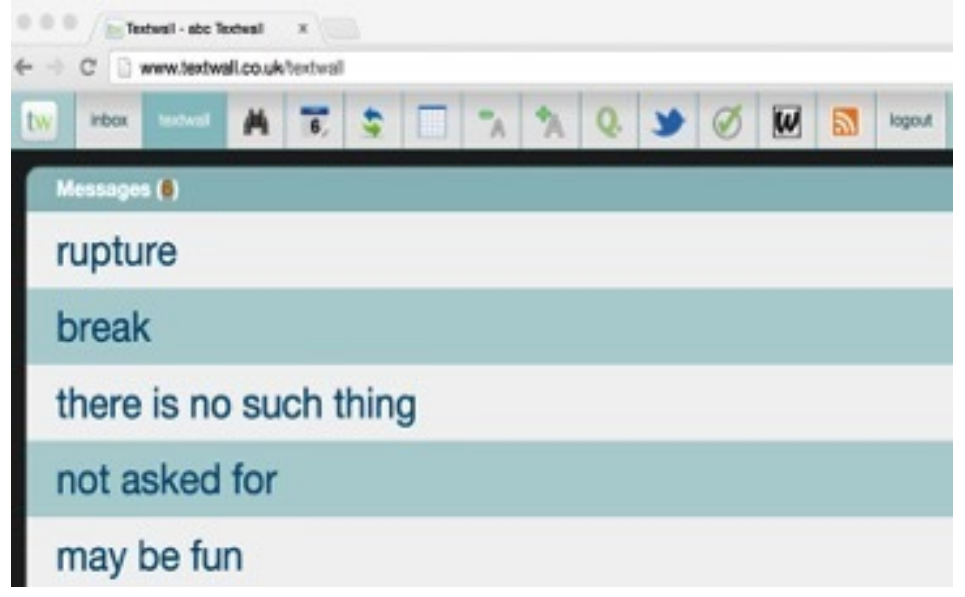

Figure 13: Postings on Textwall by students made when I asked them to post their initial reaction when they think of the term 'interruption'

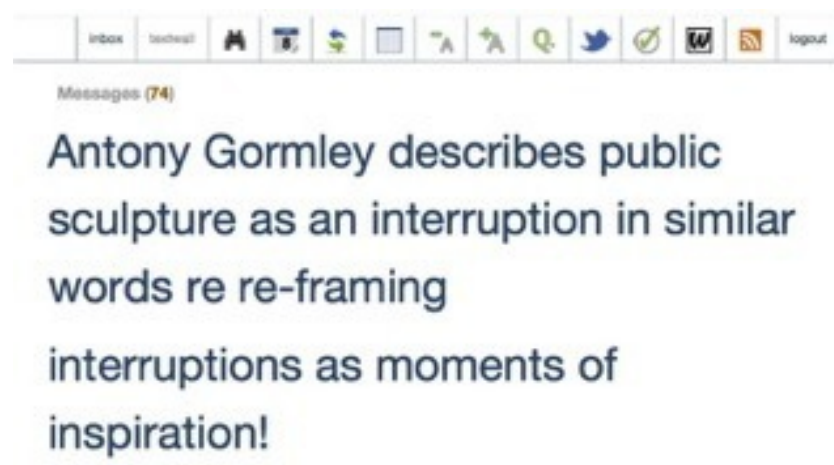

Figure 14: Postings on textwall by students made during the final reflection stage of the teaching seminar 
issues surrounding 'collaboration' through direct practical engagement with interruptive processes.

To look back and reflect in retrospect to address and evaluate the outcomes of this teaching session, I shall use a range of sources. Chiefly, I will refer to comments made by students during an informal feedback/evaluation occurring directly after the seminar. I will also refer to comments made by the peer observer. I shall also make use of reflective writing by students who engaged with similar interruptive processes that I deployed in teaching sessions at CSM and UoL.

As I shall discuss in the following sections, the main outcomes of the teaching session relate to: 1) experiential learning related to the interplay between 'collaboration' and 'interruption'; 2) performative pedagogy and inclusion; 3) the interplay between teaching, liveness and interruption; and 4) performative pedagogy and the exchange of power relation.

Experiential learning related to the interplay between 'collaboration' and 'interruption' - Holding a feedback session with the students was very useful in evaluating the outcomes of the seminar. Lasting just under an hour, the session helped consolidate the seminar's teaching and learning activities through controlled writing exercises which included the students using a range of strategies such as making notes, annotating diagrams, writing factual reports etc., with consideration of listing the different phases of engagement they underwent during the practical component i.e. the interruption activity, of the session. These helped build the students' effective reflective and critical skills through writing and rumination. Their personal reflections were mapped onto their individual blogs for them to not only reflect through writing, but to encourage them to incorporate aspects of their practice alongside research. This not only enabled them to improve their digital literacy but to demonstrate how blogs can support promotion and development of their work. In their feedback, several students expressed enthusiasm for trying my Anticipation, Action and Analysis model of practice out themselves and/or use it as a basis for developing their own autonomy by generating a similar model that encourages reflection upon action. Evidencing impact of the positive nature of students making use of this process because of this session, students commented that they found this process engaging and useful as it enabled them to evaluate different interpretations and different approaches to generating practice and several of the students said they would try and adopt a similar approach to reflecting upon their practice in the future. When I engaged in class discussion with the same students at a later date they told me that they found carrying out the process to be beneficial, an effective conceptual tool for anticipating practice, executing practice and reflecting upon that practice. One of the students mentioned that using my process and then appropriating it to suit her own practice trajectory helped her initiate a free flow from theory to practice, an aspect of her learning she had previously struggled with. In terms of the aims of the session, students told me that the session had helped them to further understanding of the 
key concepts relating to the seminar topic and as a result of my deployment of Performance-related methods to help the students understand the term 'collaboration' in practice, many of them had started to use Performance as one of the major components of their Fine Art practice. Students told me that they enjoyed listening to my description of the usage of a physical written contract in order to make collaborative work as part of my recollection of Contract with a Heckler. They commented that the stifling of formality of the contract i.e. 'getting everything in writing', being told what to do and when to do it really helped them to think about some of the (uncomfortable) implicit power relations in collaborative work because the contract helped to make explicit those power relations. Students also commented that I had helped them to develop more effective communication skills through the use of e-technology that was present during the session.

As aforementioned, my doctoral thesis (2016) brought out productive insights regarding participation and power relations in Performance Art. Contract with a Heckler was a performance related to me planting a heckler within my delivery of a research paper to discomfort the audience. Interruption to my paper was via the disruption of a security guard ordering me to leave (set up by myself and my collaborator Claire Carter). Some audience members complained that this ruined their enjoyment of my paper and felt uncomfortable at being part of an artwork without their consent and prior knowledge of exactly what was going to happen in terms of the delivery of my lecture paper, others, for instance audience member Farokh Soltani, were (positively) provoked by the discomfort embodied in the interruption to my paper:

I really enjoyed it [the discomfort Soltani experienced being in the presentation room]. After a while the discomfort gave way to 'ooh that's interesting'. What is happening is clearly an act of thought; it is an act and it's an act of thought. I can clearly understand even if the paper was not about [heckling] [...] it's about interruption and disruption and the only way that comes across is that it is completely unexpected and unacceptable and if what happened was completely acceptable, if it [the interruption] had been announced and if it had not been so uncomfortable there would really be no point in it. And when it ended and the Q and A started, I thought people would say 'Wow! That was cool!' but [they said] 'Oooh you should have warned us!' It was completely ethically justified, exactly for that reason. (Soltani, pers. comm. July 2015)

The planted 'interruption' to the delivery of my paper a taught me about using interruption in order to control an audience by disrupting their expectations of 'the presentation of critical ideas within academia' (Soltani, pers. comm. July 2015) by using practice-in-action related to physical interruptive processes deployed as tactics to undermine those critical ideas (in this case, theories of heckling) from having to be 'controlled and framed within a very specific set of regulations' (ibid.). Relating these ideas to student feedback of my session, one of the students who worked in the group instructed to interrupt the other group's performance wrote that she found that using interruption 
(albeit in a somewhat constructed and artificial way) in the contents of an performance/ art seminar presented itself as, first, an act of transgression in terms of what she referred to as the tension between the norm (for students) of behaving politely during class and the desire by some students to misbehave and secondly, the simplest technique for a participation. I then conducted an iteration of my collaboration/interruption teaching session at CSM in May 2015 for first year BA Performance: Design \& Practice students. When I asked those students who took part to reflect back on the interruption activity many months later (September 2016), their feedback echoed the potential for transgression. This can be demonstrated in the following response by one of the students, who also writes that the activity provoked her to reflect upon her practice of performance-making practice:

I thought that session was very engaging, especially being given the license to interrupt a performance and be the worst audience ever, something that would not have been conventionally socially acceptable. It was a lot more fun and exciting than I thought it would be. Also, I didn't realise back then but when I go to performances since, it made me more aware of the audience's role and reaction. Of course, I have never stood up in the middle of a performance and walked away or be a rowdy audience because there's so much social pressure to be quiet and enjoy the show but it definitely made me question my performance making. I feel the judgment of interrupting a performance comes not so much from the performers but from fellow audience because that's what societies and systems do, impose standards to follow but that's what art always challenges.

Extending when alternative comedian Tony Allen shouted out "heckling is the shortest, briefest, most neatest, tidiest way of getting an idea across quickly" during discussion taking place at Heckler (2013) in London, other students in the feedback group suggested that what they had learnt about collaboration and interruption through engaging in these processes in a practical and experiential way was that interruption can distinguish itself from related terms (antagonism, dissensus, disruption, etc.) specifically through its sophisticated deployment of physical linguistic impoliteness in order to communicate and establish an uncomfortable power relation with those person(s) their interruption is aimed at. Combining my reflection of the session with notes made at the time by the peer observer, directing my students to academic definitions at the start of the session encouraged students' critical thinking of the topic, but reinforcing them by asking particularly the hecklers to determine and apply the definition to their actions along with the definition for collaboration 'could have led to a more meaningful start' (Ingham, pers. comm. May 2015).

Performative pedagogy and inclusion - In her appraisal of the session, the peer observer commented that 'a vibrant and rich learning experience for students' was achieved and that "peer and experiential learning was strongly evident" (Ingham, pers. comm. May 2015). In terms of my own development as a 
teacher, the session taught me a great deal about some of the complexities involved when encouraging students to engage in performative pedagogic processes. More urgently, it taught me about the successes (and some of the dangers) of working with interruption; the session forced me to reflect upon issues around inclusion (generating an inclusive learning environment that includes Performance) in relation to my emotional state at the time in relation to the ambivalent nature surrounding a student temporarily exiting.

This teaching session demanded that students be confident in using performance and specifically interruption as a performative technique. Key concepts emerging from a reflective analysis of the teaching session that I have identified as areas for extension/revision in my teaching include experiential learning and using Performance methods in relation to inclusivity. The session provoked me to think more carefully about using Performance; I expect students to be confident in using Performance and be able to demonstrate personal feeling with relative ease. In relation to the teaching session discussed, whilst some students in the group could be said to be particularly extrovert and unafraid to express an opinion, others were less comfortable in doing so. The most poignant moment in the session for me was the student who got up and left (but did in fact return about twenty minutes later). I was really unsure whether she had left due to feeling so uncomfortable with the activities taking place at that moment in the session or whether it was her response to the task, the student's exit constituting an interruption. Zones of demarcation became blurry and it was this uncertainty between whether her act was 'art' (a creative response to the task in hand) or 'life' (a response leading from discomfort in how the student was feeling). When the student in question revealed to the class that her leaving was indeed her means of 'interrupting' the performance, her action (and the momentary uncertainty about its nature) provoked an immediate reaction and call for reflection (Savin-Baden 2007). Referring to writing that I produced shortly after the session, in response to the moment when the student picked up her bag, put on her coat and left the room, I wrote down exactly how I was feeling at the time and the questions that I asked myself: "Bloody hell! Have I set up a teaching activity that has really upset the student, forcing her departure? Gosh. What I have done?"

Supporting my perspective of the importance of reflection is Maggi SavinBaden, who states: "when we are engaging with reflective spaces there is sense that we are located in an interrupted world" (2007: 69). In the discussion entitled Reflection as Interruption, she ties reflection to interruption and proposes, "reflection can be seen as interruption because reflection tends to disturb our position, perspectives and views of the world" (ibid.). The importance of reflection and "choos[ing] to interrupt everyday actions through reflections and interrupt current stances by attempting to expose new perspectives and positions" (ibid.) can be argued as being essential in learning about how certain things (including the term 'interruption') operate. Indeed, it can also indicate how practice and subsequent reflection upon practice can make aspects of theory on practice more tangible. Moreover, and most 
importantly, it can highlight how reflection (provoked through interruption) can produce huge shifts in practice. ${ }^{12}$ I reconfigured reflection and interruption in terms of interruption as reflection to argue interruption as not only "enabl[ing] learning to happen" (Fry, Ketteridge \& Marshall 2009: 3) but to push forward interruption as provoking an immediate reaction and call for reflection. The 'huge shift' that occurred in my practice as provoked by interruption related to how I then began to consider my usage of performative pedagogy in relation to what the peer observer described as 'emotional inclusivity' (Ingham, pers. comm. May 2015). In my planning of a teaching session that heavily deploys elements of performative teaching and learning, I think more carefully about how I generate an inclusive learning environment that includes Performance. To help alleviate anxieties to any performative-collaborative-game-like activities that I now set up as part of my teaching sessions, I try to ensure that I set out clear expectations to students to enable them to focus on a given task in a manner which advances the learning of all (with the intention of not diluting the power of interruptive processes if these forms a major component of my pedagogic strategy for a specific class). I also accentuate a range of activities that incorporate both collaborative and individual work. Taking on the advice of my peer observer, I now set clear supportive guidelines to develop sound attitudes and professional behaviour from the start of activities in terms of the inclusive nature of learning collaboration, an important consideration especially at FHEQ Level 4 as "some students may be particularly immature" (Ingham, pers. comm. May 2015) as was the case in this group when one student decided to strip off to his underpants as his creative response to the heckling activity. I later conducted another iteration of my collaboration/interruption teaching session at UoL in October for first year BA Fine Art students. I asked students who took part to reflect back on the interruption activity to write down their responses/ideas/observations etc. a week later during an informal reflection session. When I read over their responses it was intriguing to discover that some students thought that 'subtle' interruptions would be more effective in terms of generating disruption than those persons using interruption to be loud and aggressive. To evidence this, one of the students wrote that what she had learnt from the activity was that "subtle interruptions can be the most powerful".

\footnotetext{
12 To demonstrate how reflection provoked through interruption can incur a 'sea change' of practice in other examples, in my doctoral thesis (2016) I refer to critical incidents as shaping the direction of my then research as caused by explicit moments of interruption. The most important critical incident that re-shaped the conditions of my practice and expanded the possibilities for examining different forms of interruption related to an act of physical interruption. As the result of events taking place when I participated in an artist's residency in Canada in 2012 (discussed in detail in Chapter Two), a major shift took place in developing and finalising the research questions because of a critical incident involving me being interrupted by an audience member at the start of a performance-related artwork that I set up which was dependent upon audience participation. As I describe, this key moment (the audience member's interruption) really changed my practice. Existing research questions focusing solely upon comedy tactics and participation at the time were uprooted and the nature of future practice-as-research relating to the questions that I was to then ask of and through my practice re-imagined. The audience member's interruption was a key moment underpinning the next stage of research.
} 
Another student, helpfully referred to different "scales" of interruption, asking, "Subtle or loud [interruption] - what is worse?" These sentiments echo the situation that occurred in Loughborough where the student whose interruption had the capacity for more disruption could be argued as being the student who left the room quietly for ten - twelve minutes than the student who thought that he was being [the most] provocative by taking off his clothes, leaving on only his Calvin Klein boxer shorts. I now check with students that they are overtly aware of the specific requirements of a task and underline to them the importance of being responsible in terms of the appropriate nature of their interactions with others. The inclusivity of and initial guidance for any performance-related activity at the start of a teaching session has become key. Another student who took part in the activity at UoL wrote "intensity", "overwhelming", "noise", "anxiety", "pressure" and "drowning". I am keen to speak further with the student about these responses, as it is important for me to understand how the students could potentially recognise these terms constructively for the student to generate art practice. It is important to note that this student has expressed to me that they have mental health issues. ${ }^{13}$ It is my role now to set up a safe space for all students to be able to actively engage in experimentation risk-taking in their practice in a manner that does not discomfort/upset them.

The interplay between teaching, liveness and interruption - Where I spoke of anxiety and trepidation that I felt at the time in the last section, this supersensitivity may have been caused by my practice as a performer; I am aware of the complexities involved related to processes, practices and concerns within Performance. ${ }^{14}$ These can include 'audience', 'liveness' and 'observation' (Alasuutari 1996; Freshwater 2009). Peer observation can be a method/tool for evaluating the effectiveness of teaching. I have interrogated 'liveness' and 'observation' as key concepts within my own research and practice to demonstrate that I am aware of some of the issues related to the term in reference to my subject discipline (Performance Art) drawing upon a range of literature sources dealing with what it may mean to be an observer and a teacher who is observed (Fullerton in Fry, Ketteridge and Marshall 2003; O'Leary 2014 et al.) 'Audience' is paramount to what I do (I do not want to make a performance without an audience watching me). Aspects of my early doctoral research (2010-2016) at LU explored some of the problems associated with the act of viewing, witnessing, of observing. Philip Glenn points to some of the problems of 'being observed': "observing (even subtly recording) inevitably has some influence on data, however slight it may be" (2003: 40), even referring to an "Observer's Paradox" (ibid. 14), I am interested in how the audience may change the outcome of the event, the performance, through their 'observation.'15

\footnotetext{
${ }^{13}$ For a copy of this student's response, please refer to Student Response 3 in Appendix 4.

${ }^{14}$ For a copy of this student's response, please refer to Student Response 3 in Appendix 4.

15 For further discussion on the relationship between teaching and peer observation, see: https://explorationthrougheducation.com/2016/10/06/the-classroom-observer-
} 
I argue that interruption accentuates 'liveness', an important concept for students of performance art to understand. ${ }^{16}$ Teaching and learning is a live process and the teacher needs to be on full alert, ready with methodological survival tactics such as 'improvisation' to deal with the serendipitous nature of teaching and learning as a two-way process between teacher and learner that is a process which is intrinsically live. Accepting the serendipitous nature of working with liveness, the question is how do we, as teachers cope with the chaos of liveness? I argue that the answer is found in "a bricolage of improvisation and intuition as methodological survival-tactics." ${ }^{17}$ For me, the danger that liveness can throw up is half the excitement of teaching and being a performance artist; "coping with the unexpected is an important part of successful teaching" (Race 2009: 20). In this light, the performance of interruption can be seen as an explicit form of liveness that raises many important questions and points to a politics of surprise, which I shall discuss in more detail in the following section. ${ }^{18}$

Emphasising consideration of the student experience during the teaching session, I suggest that students experienced the nature of liveness, albeit in a somewhat artificially constructed setting. As part of CPD that I was engaged in at the time, prior the teaching session, I conducted a peer observation of one of my colleagues giving a seminar on Theatre and Performance on the subject of liveness. I wanted to see how the lecturer was able to get a group of first year undergraduate students to grips with the (rather tricky) concept of 'liveness' (especially given the students' limited knowledge of the philosophical foundations of Performance at that stage in their studies). Rather than asking students to read huge amounts of text related to theories on liveness, as was the case I discovered with the Theatre and Performance seminar, I wanted students in my teaching session to experience liveness in practice.

Rather than me setting up a situation where a group of students were to interrupt another group whilst they made a performative action (with the performers having no warning that their performance may be interrupted/disrupted in some way), when I taught a group of first year BA Performance: Design \& Practice students at CSM in June 2015, I told the students performing that at

\footnotetext{
unwanted-interruption-or-welcome-witness/

16 The term 'liveness' is often used within the context of Theatre and Performance to describe the relationship between experiencing something live as opposed to a recording/mediatised version of a live moment. Peggy Phelan (1993) and Philip Auslander (1999) offer contrasting perspectives, which I have found useful in helping students understand the importance of liveness to Theatre and Performance. Phelan argues, "Performance's only life is in the present. Performance cannot be saved, recorded, documented" (1993: 146), whilst Auslander argues that "it is not realistic to propose that live performance can remain ontologically pristine or that it operates in a cultural economy separate from that of the mass media" (1999: 40).

18 In reference to some of the contemporary issues surrounding 'liveness', performance for me is predicated on liveness and the embodied phenomenological experience of 'being there' i.e., first hand witness. As a practitioner who uses performance as a tool, I recognise that I work within a context that is dualistic, a form of creative practice that is composed of two historical traditions (art and performance) The trace of an event circulates and becomes new and takes on new forms; its reiteration undermines and challenges the idea that you have to be there.
} 
one point during their performance they would be interrupted. Whilst some students who performed bemoaned the interruption as ruining what they had planned, other students in the same group found that the interruption in their performance forced them to think on their feet and act creatively, imaginatively and inventively as evidenced in comments made by the students during an online webinar that I held a week after the session. Despite knowing that an interruption was inevitable, this caused anxiety for some, for others it enabled them to pull in all their resources and think how they were going to combat or use this (interruption) to their advantage during their performance. Another set of students criticised the group who had been assigned to interrupt their performance for not interrupting, referring to a wasted opportunity for them (the performers) to show off their prowess and wits when faced with interruption, like comedians defeating hecklers with put-downs and verbal barbs (Campbell 2014; Hound 2011).

Performative pedagogy and the exchange of power relation - Whilst my doctoral thesis explored the subject of power dynamics at play in participative performance by using my practice to seek out tactics (such as interruption) that would enable exposure and analysis of their mechanisms, my usage of interruption in the classroom as explained throughout this paper can be a very useful tool for making visible similar exchange of power relation in pedagogic settings.

My focused usage of interruption within pedagogy offers support and extension to the related work of Peter Bond (Lecturer, Performance: Design \& Practice, CSM, Alex Schady (Fine Art Programme Leader, CSM) and Fred Meller (Course Leader, Performance: Design \& Practice, CSM). As part of a roundtable discussion taking place at Tactics of Interruption, Toynbee Studios, Artsadmin, London, ${ }^{19}$ Bond highlighted a teaching activity where he stages a phone call, asking a colleague to interrupt a lesson by phoning him on his mobile phone at a certain time, to which Bond answers:

Pause (listens) [...] "Yes, chicken tonight", pause "maybe broccoli", [... " "no, French beans" Pause (listens) "Thank you darling, bye darling", [....] love you (Bond, pers. comm. October 2016)

In the discussion, Bond referred to interruption as an educational process and that teaching is about reproducing real life in the classroom (Bond 2016b); to reproduce real life effectively then we need to incorporate aspects of interruption. How do the students react to this staged interruption? "I have done this 'action research' at least 3 or 4 times and in all cases no one [the students] has battered an eyelid!" (Bond, pers. comm. October 2016). Did the students react in this way because they: a) assumed that the phone call (the interruption) was staged and may have deemed this staging as an 'inauthentic' interruption, or, b) they were stunned by Bond's act of transgressing the accepted norms of classroom behavior i.e. turn mobile phones off by answering his phone (an unplanned phone call) during one of his lessons? Honing in 
on power relations complicit within learning and teaching, although Bond is using the mobile phone call as interruption to incur a sense of liveness - by him conducting an action that students are told not to do during class (answering phone calls), he adds a further layer to the teacher-student power relation that is already at play i.e., by Bond (the teacher) answering his phone, he is demonstrating that he is in a greater position of power than his students. Maybe the students were non-reactive because some of them thought that this was a 'genuine' interruption and were reminded of the power relations at play between themselves and Bond. In answer, Bond suggests that the students "normalised the situation. They believe because I am a tutor, more important than them (or so they may believe), it is my right to answer the phone. They normalised it. They mythologised it. The teacher/pupil scenario ... (all the things that I work at breaking down)" (Bond, pers. comm. October 2016).

For me, interruption is a successful technique in reminding us of the implicit power relations at work in the pedagogic process. Its power, as I have addressed in terms of the student walking out of my class - is that it can quickly overturn / switch those power relations between teacher and students. Fred Meller's work (2015) on the potential of a pedagogy comprised of performative aspects is important in this context as she suggests that performative techniques as played out by the teacher/disruptor/trickster, "conversely maintains and upholds the power relationships and ideologies of the Institution" (ibid. 2) going on to argue that "learning about our teaching process and performance making process and how they are inextricably linked could mean that we might also learn how to disrupt this process and in so doing be empowered to challenge the orthodox" (ibid. 3). What is the potential of interruption to explore power relations attached to pedagogy in terms of teacher/student roles? Potential claimants for Meller's role for disruptors and tricksters (ibid. 43) deploying acts of performative pedagogy Alex Schady and I both consider our teaching (and deployment of interruptive processes within it) as a form of practice to examine the often tricky and difficult nature of pedagogic exchange and corresponding levels of power relations. To explain, I define power relations in terms of pedagogy as analogous to the relationship between protagonist and audience in terms of participative Performance Art; I (protagonist) do this and you (audience) do that.' In participative Performance Art the notion of democracy (all participants having equal status in terms of power) is suspended; 'I do this and you do that' underpins the form. My doctoral thesis (2016) positioned its appraisal of Performance Art predicated upon audience participation as ontologically rooted in unequal distributions of power. Nicolas Bourriaud (1998) sees Relational Aesthetics as describing participatory art encounters where everyone is nice to one another (being friendly and convivial) and everybody is equal in terms of their power status; in these terms there are no power relations and there is a shared sense of democracy. In relation to participation and power relations, I describe my work as not wanting to alleviate social imbalances of power in participative performance and subsequently in pedagogic teacher/student exchange nor to reinstate them but simply to draw 
attention to them and use the practice of participative performance as a vehicle in which to initiate discussion of how social power operates in all aspects of our lives (Foucault 1980). By using my practice to expand this theory, I argue that Relational Aesthetics proposes a false notion of democracy and that any theory of participative practice, and any social relation, must give consideration of power relations. (Unequal) power relations lie at the very core of the practice of participative performance and my work extends the debate on participation by using interruption as a tactic relating to practice. My practice attempts to make those power relations explicit rather than implicit. The work of Claire Bishop (2004) questions Relational Aesthetics by drawing inspiration from how Michel Foucault describes power as underpinning social relations (Foucault, 1981), whereas my work uses practice rather than theory to make explicit the implicit power relations that underpin participative practice. Picking up on Michel Foucault's understanding of a social version of the term 'power' (1980), I generate participative art performance as mirroring the 'mechanisms of power' (ibid. 51) that takes place in all forms of daily human existence. In terms of power relations within pedagogic processes, during an interview with Alex Schady in October 2016, he explained his fascination with "power structures inherent in a teaching situation" (Schady, pers. comm. October 2016), how he has generated performative situations in order to make power relations "apparent and potentially abused" (ibid.) and suggested the following:

I think what you have to do is make it (power relation in pedagogic processes) visible. Through making it visible, you don't level the playing field but you make everyone aware of where they are in that playing field. And so I've made a series of works ${ }^{20}$ that work with that - some of them are more about disruption than others. (ibid.)

Schady made specific reference to his previous usage of interruption during a lecture that he gave at Chelsea College of Arts related to teaching Fine Art and innovative forms of pedagogy. He then informed me that during the lecture at regular intervals a number would flash on the screen behind him. The number would correspond to an envelope that was amongst someone in the audience the audience knew that if the envelope was opened they were invited to open that envelope and inside would be a command that gave that person permission to interrupt the lecture. Schady went on to state:

And so some of them [the interruptions] were fairly mild, like just saying 'boo' and others involved coming up and drawing a moustache and glasses on my face. Others involved throwing a glass of water in my face. [Interruption] used to affirm that they [power dynamics] are there [...] I do think that by pointing it [this power dynamic] out, there's the hope that they [the students] might challenge it or they might try and invert it. It would be much richer for the students to try and challenge that power dynamic [...] They become politicised, that can be very fruitful if difficult to manage (laugh) (ibid.).

In reference to my teaching session at $\mathrm{LU}$, exchange of power relation can be said to take place between three sets of 'participants': me as the teacher, the students 
as an audience and a colleague of mine from Loughborough University's Centre for Academic Practice as a 'third' participant/second audience. An (uncomfortable) power relation was set up between myself and the students, the observer and I and the observer and the students. Whilst the power relation that exists between a teacher and students could be argued as one where the teacher maintains a higher position of power, during this teaching session, that power exchange was disrupted in the first instance by the fact that I was being observed by one of my colleagues (which at times caused me to feel anxious), and in the second, by the student who temporarily exited. Her 'interruption' can be linked to Schady's sentiments above. By leaving momentarily, the student became politicized insofar as her actions affected both me and the other students. When this 'interruption' took place, I was worried that the student walking out would make me look bad in front of the observer. I was also worried about how this looked to the students. Despite my concerns of a loss of power and control in front of both my students and the observer, I enjoyed the discomfort that this situation presented. Whilst Schady has invited students to sabotage his teaching delivery as a means of shifting power relations and likes the fact that he doesn't know exactly what form the students' interruption will take (their actions constituting a certain degree of surprise for him), I argue that the student's exit during my teaching session at LU used interruption as a performative tool to unsettle conventional teacher-student power relations in a manner that was far more disruptive than similar attempts made by Schady and his students. I had no idea that the interruption activity that I set up would affect me. To analyse further, her interruption disrupted my understanding at the time of how I had thought that I had set up a supportive learning environment by setting out clear expectations to students to enable them to focus on a given task in a manner which advances the learning of all. The ambivalent nature of her action (is it 'art' or is it 'life' or an amalgamation of both?) took me by complete surprise and jolted my senses to such an extent that, in support of Savin-Baden (2007), the situation forced me to reflect, there and then on my strategy of using performative pedagogy in the form of interruption and its potential impact on student inclusivity/wellbeing. The situation provokes important questions not only in terms of what we constitute an interruption to be 'Is an interruption an interruption when you know it's going to happen?', it also forces consideration about the usage of 'surprise' tactics in the classroom: 'How much should teachers pre-warn students about the possible contents of a teaching session if interruption and disruption structurally underpins the pedagogic processes at play within a teaching session being delivered?' How does this forewarning potentially effect creativity and room for experimentation? Does it support or does it suffocate?

\section{Conclusion}

This paper has attempted to inform the reader about how I have made use of performative techniques to increase levels of participation in teaching and 
learning from both the point of view of learner and teacher from early attempts in my teaching as an EFL instructor to attempts at deploying interruptive processes within my pedagogy strategy currently as an extension of practice-as-research doctoral studies that examined and promoted the power of interruption in practice.

Tactics of performative pedagogy can be extremely useful in generating a dynamic, creative and fluid learning environment. The tactic that I have chosen to focus upon throughout this paper has been primarily interruption and its performative dimensions, alerting readers to how it can be used effectively to provoke participation but also to its limitations e.g. as I have discussed, the emotional impact on the student experience of working with interruption as an explicit form of performative technique and of using interruption as a means to command one's presence to be noticed and voice be heard amongst an audience (as evidenced in the post-it note discussion illustrated in Figure 12 where a student has written 'notice'). Some students may feel uncomfortable about being 'noticed' whilst others deliberately try to make themselves appear the centre of attention no matter how far they breach codes of responsibility within the classroom. Yet, for some students engaged in the interruptive processes that I encouraged them to take part in during the discussed teaching seminar, the experience was positive as they learnt that interruption can, and referring back to the views on interruption by Maggi Savin-Baden, hold significance in terms of forcing critical reflection including and beyond pedagogic and artistic processes in greater depth. This can be further evidenced in reference to additional comments made by a UoL Fine Art student, "interruptions make you think and observe more due to multiple things/scenarios occurring at one time whether expected or unexpected." This can also be evidenced from the point of view of a teacher, Peter Bond (Lecturer in Performance: Design \&Practice, CSM) who has made usage of interruption in his teaching sessions: "first it's [interruption] panic - and then it's reflection - it's a critical incident - it's transformative" (Bond 2016b).

An important question that this situation presents relates to context: is interruption an effective form of performative pedagogy in all settings? Is it, for example, more suited to those involving a greater level of critical thinking and collaboration e.g. my performance art seminar described, rather than, for example, an EFL setting which this paper has previously discussed elements of. Teaching and performance both have aims; teaching and performance are about communication. Art and performance is all about disruption; they are both forms of dissent, dismantling, deconstructing etc. (Roelstraete 2012). ${ }^{21}$

\footnotetext{
${ }^{21}$ Visual arts exhibition Feast: Radical Hospitality in Contemporary Art at the Smart Museum of Art, University of Chicago in 2012 explored how artists and performance makers have interrogated the term 'hospitality'. As a support for the exhibition, the museum staged a symposium where one of the panel sessions entitled Being Bad asked speakers and audiences to reflect upon artistic situations that deploy being a 'bad host' to explore the intersection between art, hospitality and 'badness' i.e., the 'inhospitable'. Exploring participation modelled as hospitality, Dieter Roelstraete explored the intersection between art and hospitality, announcing 'distrust at courtesy' and that we should remind ourselves of "art's long interest in the inhospitable", citing
} 
Parallels can be drawn between Dieter Roelstraete's (2012) insistence that art has the capacity for disruption, the staged interruption taking place during Contract with a Heckler and subsequent usage of interruptive processes in the classroom and similar pedagogic strategies by Peter Bond, Fred Meller and Alex Schady as vignettes of disruption in order to argue that Performance Art (and Art per se) is predicated on rule-breaking, even on discomforting audiences, especially the elitist audiences of Live Art and Performance. Furthermore, Farokh Soltani's (Soltani, pers. comm. July 2015) reaction to my staged interruption in Contract with a Heckler really speaks of the (positive) nature of discomfort at work insofar as it helps to set out how interruption differs from or aligns with notions like antagonism, dissensus, disruption, etc. Therefore, it could be argued that interruptive processes are more suited to teaching situations relating to art and performance as their potentially disruptive nature helps in terms of communicating the potential for disruption in art/performance unlike in settings such as EFL where disruption is not a prerequisite for learning how to be fluent and accurate in English ability.

Working with performative pedagogy in an extreme form like interruption on a theoretical, practical and emotional level can be exciting, provocative and dangerous. As Jane Munro, Lecturer in MA Advanced Theatre Practice at Royal Central School of Speech and Drama, London usefully pointed out during the roundtable discussion at Tactics of Interruption (2016), interruption is about "creating new forms - allowing interruption to shape the work - not hiding them" (Munro 2016).

\section{Acknowledgements}

I wish to acknowledge the support of Dr Deena Ingham at Loughborough University's Centre for Academic Practice for her invaluable comments in the development of this writing (and for being an unflinching observer).

\section{Bibliography}

Alasuutari, Perrtti (1999): Rethinking the Media Audience. London: Sage

Arlander, Annette (2009): Event scores for performing interruptions. In: Mäntymäki, Tiina \& Mäkinen, Olli (eds.): Art and Resistance. University of Vaasa. Research papers 290

Auslander, Philip (1999): Liveness: Performance in a Mediatised Culture. London: Routledge

Benedetti, Jean (1989): Stanislavski: An Introduction. Revised edition. Original edition published in 1982. London: Methuen

Billing, Johanna; Lind, Maria \& Nilsson, Lars (2007): Taking the matter into common hands: On contemporary art and collaborative practices. London: Black Dog

Bilmes, Jack (1997): Being interrupted. In: Language in Society 26, 507-531

terms such as dissent, disgust, discomfort, dismantle, dissatisfaction etc. (Roelstraete 2012). 
Bishop, Claire (2006): Participation-Documents of Contemporary Art. Cambridge, MA: MIT Press

Bond, Peter (2016a): Personal communication with the author (October 2016)

Bond, Peter (2016b): Comments made as part of roundtable discussion at Tactics of Interruption, Toynbee Studios, London (June 2016)

Bourriaud, Nicolas (1998): Esthetique Relationelle (English translation by David Macey 2006 as 'Relational Aesthetics'). Dijon: Les presses du reel

Bousfield, Derek (2008): Impoliteness in interaction. Amsterdam; Philadelphia: John Benjamins Pub

Brixey, Juliana; Johnson-Throop, Kathy; Walji, Muhammed \& Zhang, Jiajie (2004): A theoretical framework to understand and engineer interruptions. Presentation at the 26th Annual Meeting of the Cognitive Science Society

CPD Certification Service 2016. https: / cpduk.co.uk/explained [last accessed August 17, 2016].

Campbell, Lee (2016): Tactics of Interruption: Provoking Participation in Performance Art. Unpublished PhD thesis. Loughborough University

Campbell, Lee (2014): Heckler, Performance, participation and politeness' using Performance Art as a tool to explore the liminal space between art and theatre and its capacity for confrontation. In: Remes, Outi; Leino, Mariko \& MacCulloch, Laura (eds.): Performativity in the Gallery: Staging Interactive Encounters. Oxford: Peter Lang Ltd

Cotter, Suzanne \& Tawadros, Gilane (2009): Transmission Interrupted, exhibition catalogue. Oxford: Modern Art Oxford

Foucault, Michel (1981): The history of sexuality (translated from the French by Robert Hurley). [Vol.1] Harmondsworth: Penguin

Foucault, Michel (1980): Power/knowledge: selected interviews and other writings, 1972-1977 (ed. by Colin Gordon). Brighton: Harvester Press

Freshwater, Helen (2009): Theatre and Audience. Basingstoke: Palgrave MacMillan

Fry, Heather; Ketteridge, Steven \& Marshall, Stephanie (2009): A Handbook for Teaching and Learning in Higher Education: Enhancing Academic Practice. London: Routledge

Fullerton, Helen (2003): Observation of teaching. In: Fry, Heather; Ketteridge, Steven \& Marshall, Stephanie (2009): A Handbook for Teaching and Learning in Higher Education: Enhancing Academic Practice. London: Routledge

Glenn, Philip (2003): Laughter in Interaction. Cambridge: Cambridge University Press

Gunning, Tim (1995): Response to 'Pie and chase'. In: Karnick, Kristine B. \& Jenkins, Henry (eds.): Classical Hollywood Comedy. New York: Routledge

Higgins, Dick (2001): Intermedia. In: Leonardo 34/1, 49-54

Hound, Rufus (2011): Stand-Up Put-Downs. London: Bantam Press 
Ingham, Deena (2015): Personal communication with the author (May 2015)

Kendall, Bridget, Roda, Claudia, Russell, Gerrard \& Tannen, Deborah (2015): BBC World Service's The Forum: Interruptions. Broadcast date: January 13, 2015

Mansell, Damien (2016): Flipped Learning. In: Viewfinder: The Journal Of The British Universities Film and Video Council 103, 8-9

Meller, Fred (2015): Performing teaching: Seeing teaching through a lens of performance in Performance Design and Practice. Unpublished postgraduate thesis, University of the Arts London

Munro, Jane (2016): Comments made as part of roundtable discussion at Tactics of Interruption, Toynbee Studios, London (June 2016)

Newbold, Carol (2016): Personal communication with the author (January 2016)

O'Leary, Matthew (2014): Classroom Observation: A Guide to Effective Observation of Teaching and Learning. London: Routledge

Phelan, Peggy (1993): Unmarked: the politics of performance. London: Routledge

Race, Phil (2009): Using peer observation to enhance teaching. Leeds: Met Press

Roelstraete, Dieter (2012): Responses to presentations. Presentation at the Smart Museum of Contemporary Art

Rolfe, Gary (2001): Critical reflection in nursing and the helping professions: A user's guide. Basingstoke: Palgrave Macmillan

Savin-Baden, Maggi (2007): Learning Spaces: Creating Opportunities for Knowledge Creation in Academic Life. Maidenhead: Open University Press

Schady, Alex (2016): Personal communication with the author (October 2016)

Soltani, Farokh (2015): Personal communication with the author (June 2015)

Wigmore, Heidi (2010): Personal communication with the author (June 2010) 


\section{A Appendices}

\section{A.1 Appendix 1: Lesson Plan}

\section{A.2 Appendix 2: Contextual information relating to Performance and Collaboration teaching session}

Having provided students with a general contextual framework of contemporary artists working as collaborative duos including Tim Noble and Sue Webster and Gilbert and George, I gave student three examples from my own practice where I have worked in collaboration with another/others which contained varying levels of failure and success. The first related to collaborative work I have made with artist Frog Morris as demonstrating positive collaboration. I gave the students a copy each of this description by Gary Stevens of collaborative work Morris and I produced for the exhibition Archipelago at Café Gallery Projects, London in 2011.

The second example that I gave referred to collaborative work with artist Aimee Chuter as demonstrating how to overcome problems that may arise when working collaboratively as a duo. I informed students how our collaborative performance Leap of Faith, first performed at the Mead Gallery, Warwick in 2002 and then shortly after at the Howard Johnson Hotel, West Bromwich produced interpersonal tension and communication breakdown between Chuter and I. I then explained that as result of me building my experience and awareness of creating site-responsive artworks, Chuter and I worked collaboratively together again in 2006, producing the performance Mind/Fall Down at Cockpit Theatre, London. I supplied students with details of how, in this instance of us working together, we prioritised the importance of site as informing the context of our work and its subsequent effect on audience reception. The following figures (Figures 18-19) were shown to students as PowerPoint slides.

The third example that I gave students related to my participation in an artist-in-residence programme at Braziers Park in Oxfordshire in 2010, as demonstrating some of the issues involved when working in collaboration with more than 2 people, in this case, with 17 people as part of Braziers International Artist' Workshop (referred to as BIAW thereafter). ${ }^{22}$

\section{A.3 Appendix 3: Copies of Handouts relating to Public Symposium ${ }^{23}$}

\section{A.4 Appendix 4: Student Responses}

A.4 Appendix 4: Student Responses

\footnotetext{
22 See: http://www.braziersworkshop.org.uk/

23 Thanks to Vanessa Jackson for compiling these notes.
} 


\section{TEFLTASTIC! \\ SCHOOL OFENGLISH \\ 989-999 OXFORD STREEI \\ LONDON W1}

"Your key to success!. Be the best!" INDMMASIDC

\section{LESSON PLAN}

Date: 24.06.2010 Class: 13a Level: Intermediate Room: Conference room 1b

Class Profile: 1x Austrian, 1x Italian, 2x Korea, 1x French, 1x Ukrainian, 1x Russian, 2x Japanese

Aims: to make students aware of language to deal with difficult and awkward questions in business situations: 'How to succeed at Business English: Lesson \#23 addressing awkward questions (and look smart)'

Materials: don't use obsolete, outdated equipment (e.g. whiteboards, marker pens, OHPs etc) use the most up to date technology: portable digital projector, Mac Powerbook, iPad, business English bible: 'Ruthless Business Practices: I don't care about anyone accept myself' by David L Cashe.

Anticipated problems: certain laugauge which can be misinterpreted (informal language used in a formal situation)

\begin{tabular}{|c|c|c|c|}
\hline Purpose of stage & Interaction & Description of stage & Time \\
\hline $\begin{array}{l}\text { Correct students } \\
\text { pointing out the } \\
\text { different expressions } \\
\text { and phrases } \\
\text { differentiating } \\
\text { between 'right' and } \\
\text { 'wrong', formal and } \\
\text { informal }\end{array}$ & $\begin{array}{l}\text { Ask } \\
\text { students if } \\
\text { any of them } \\
\text { have } \\
\text { experienced } \\
\text { a situation } \\
\text { that } \\
\text { necessitated } \\
\text { answering } \\
\text { awkward } \\
\text { questions } \\
\text { Students to } \\
\text { practice } \\
\text { saying } \\
\text { expressions } \\
\text { in groups of } \\
\text { three - lots } \\
\text { of lively } \\
\text { drilling! }\end{array}$ & 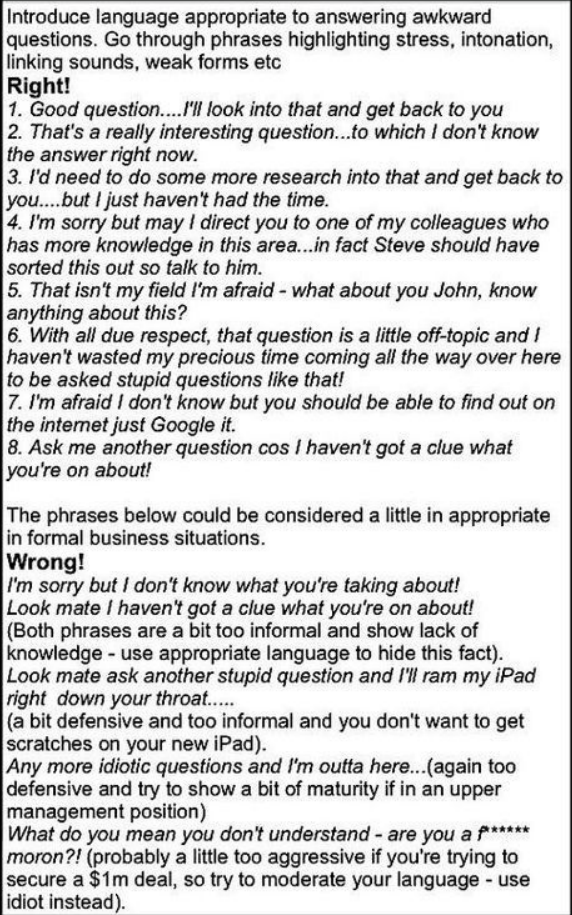 & $30 \mathrm{mins}$ \\
\hline
\end{tabular}

Figure 15: Handout 1. 


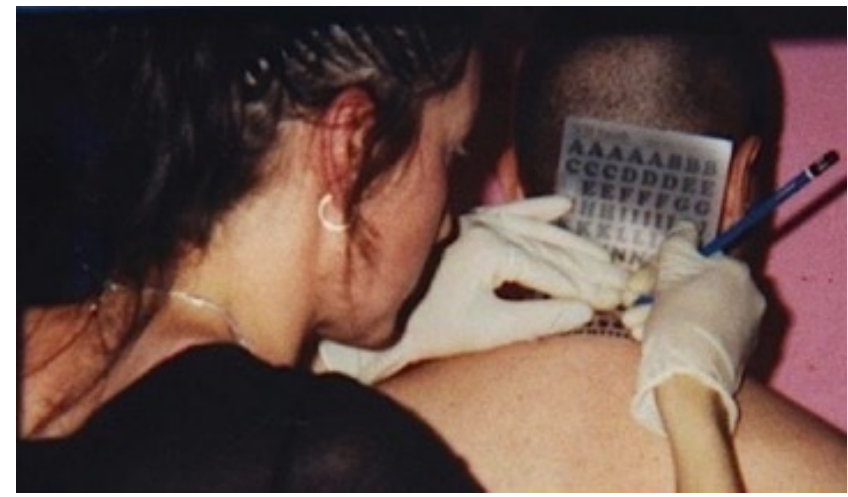

Figure 16: Lee Campbell and Aimee Chuter, Leap of Faith, Howard Johnson Hotel, West Bromwich, 2002

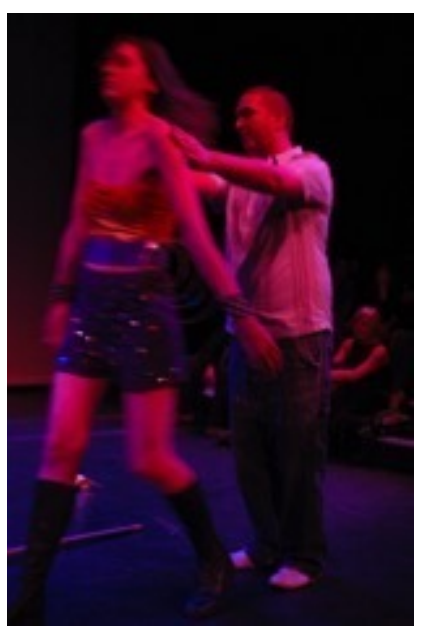

Figure 17: Lee Campbell and Aimee Chuter, Mind/Fall Down, Cockpit Theatre, Paddington, London, 2006 
Lee Campbell

COLLABORATORS AND HECKLERS: Performative Pedagogy and

Scenario

Interruptive Processes

Volume $2017 \cdot$ Issue 1

Steepen Iou stor

Conversation Rospondiy to structure Artists response -

Performatint -

Ob of to do sometting/Rigid structure.

Trust - equality in the collective.

Letting go of authorship.

Acceptance

Dissent. I Fragility.

Conectwe Respect for Difference.

1. Whats going on

2. TRue Collaboration

3. Impossible / Wrong Approach.

4 Small groups.

S-Lect alone/ group space.

6. PROJECT based activities

7. Structured to ensure all participated.

8.- Social experiment

9. More than the Som A parts

1. Abandon Authorship - How?

2. Consensus or dissent.

3. FUN.

3. FUN
2. USualing good thins to do.
5. Documantorion

6. Expected model.

7. The unexpected.

8. Selected to Collaborate.

Discussion A difference Ratter than Consensus. You might not know about "When you are conobovating How does it get made. How do you trust it

It is a "fragile" + a Living process"

Figure 18: Handout 2. Notes made by Stephen Johnstone

67 
Jonathan Parsous Fable.

Big discuesion about the dufferent types of' "exchange" - artistic, social ad

financial. - Good will or monetry.

Expectations for the 17 artists wovicy as a comective - and how thrir exchangs was manifented with Nis financial imput. Frundry beecame a bigdeloatt with the gravp - Yor har to be fit.

"Super normal"

Personal investment - Varied betwon aptists. who are used to dome suppont ad those from countries when Hers is no support for the Grets - Mone funding the greatir He expecta hoins.

- Discussias about struative of W'shap.

ths "TyRamy of beeng, with out Stenotum" Lack At Clarily - meant the 17. Just had to get on with af Co-ardination too busy with Festival sele imposed Rults. No leaders. Splintering of the majority. "Weotarner had biggest problems with authorty. ego's UK ARturts on "Rails" of thisking + production. But - evenonally. Respousibility + generosity. Bbandacy Authorshi * to question How wa Consorre Culture -

Figure 19: Handout 3. Notes made by Jonathan Parsons 
Lir Whithend.

- Experience for the Vositire -

Andicina opportinity. Is the Fortwal the centu. - Where do the arturss fit in. Public

Access to the Art. "Where is the aet".

"The artiss are in the restral" - "drowning

Intinesting to see how low fundy affects practice. and aretiss from out ride the UCe found the "fundry fo cussed conversations - jus" currous"

CMectrity - "one brain". Querting of art/tgo NeAwrelecy Important' AND mentoring produces the oppoctunity for Artirts to staret/build relatimships - Faceborle - Braziers - Proper Cuttura ifiochays.

- Diffinent sonts of warky.

Conechiv wouling.

Collectiva.

Collaborating.

Questrang A Ego/Art

Compromue?

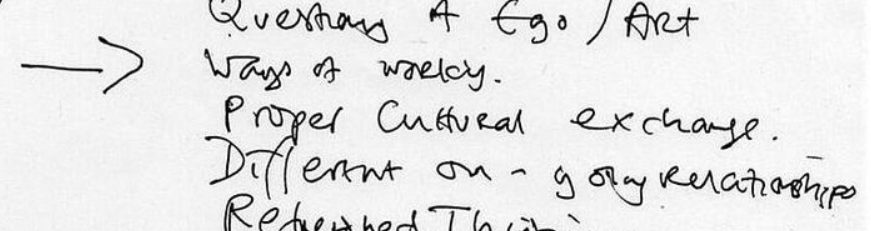

Consensus.

Proper cuttural exchayse.
Differtnt on - goryreratioshipo

Refresned Thriking.

Cooking

Inter natraial

RuRal / urban

Negatin. counotanos of the "coluaborntipe " can be pouvifol (colusion with the enemg) - and gors against Natural artiste instiricts

Figure 20: Handout 4. Notes made by Liz Whitehead 
How did the activity we have just undertaken made you think more about (the creative potential of ) interruption / using interruption in a sophisticated way?

Please jot down your ideas here:

$\rightarrow$ chaotic

$\rightarrow$ subtce interrupnions can be the most powerful

$\rightarrow$ it can begin at any point whether within the piece by the arnist or from a heculer

$\rightarrow$ interruphon is viewed as rude and insulting but the uinds of interniptions you can make un art can mave pieces mone inviguing or be viewed as puasing. interruphions mave you thine and observe move duve to mulniple things/scen arios occuring at one thme whether expected or unexpected.

Figure 21: Student Response 1 
How did the activity we have just undertaken made you think more about (the creative potential of ) interruption / using interruption in a sophisticated way?

Please jot down your ideas here:

* different scales of interruption - subtle or loud what is worse?

* the reactions to interruption-when you don't know its going to happen its like the automatic spontaneous reaction to this.

RI think each person would react differenty to unterruption or bevig interupted depending on how it makes them feel.

Figure 22: Student Response 2

How did the activity we have just undertaken made you think more about (the creative potential of ) interruption / using interruption in a sophisticated way?

Please jot down your ideas here:

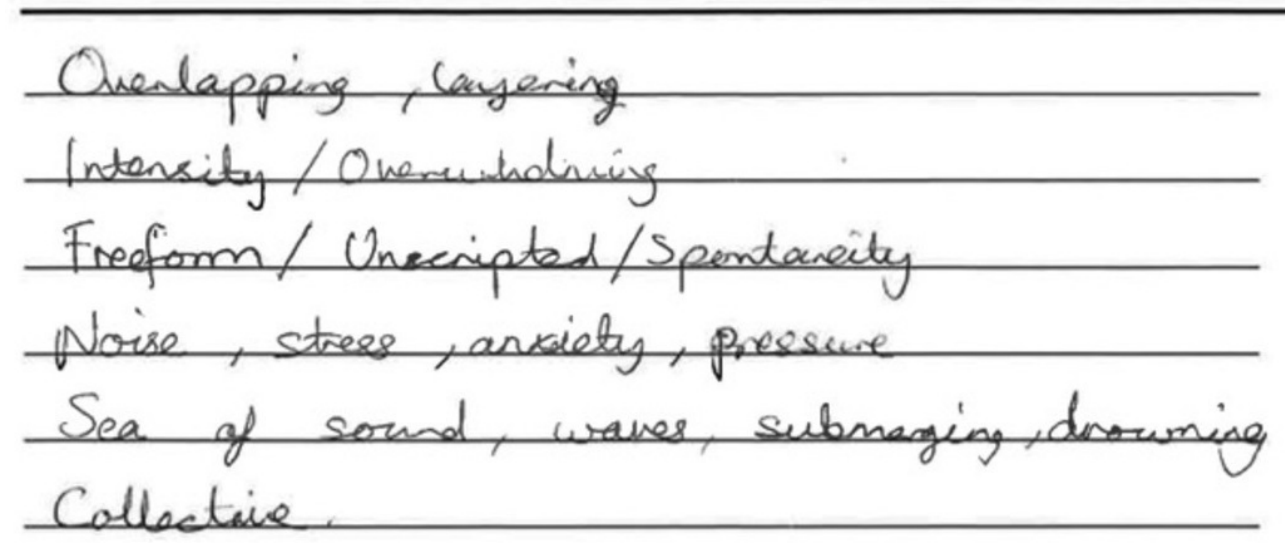

Figure 23: Student Response 3 